\title{
Acute mastoiditis with facial paralysis as initial symptom of acute myeloid leukemia relapse: a rare case report
}

\author{
Levent Yücel ${ }^{1 *}$ (D), Hazan Başak² ${ }^{2}$ and Süha Beton²
}

\begin{abstract}
Background: Extramedullary involvement of leukemia usually occurs in the skin and central nervous system. Isolated leukemic involvement of the temporal bone is a very uncommon situation, and it is seen frequently concomitant to hematologic or molecular relapse.
\end{abstract}

Case presentation: An 8-year-old male with acute myeloid leukemia (AML) M2 with t $(8,21)$ (FAB classification) in remission for 2 years was referred to our clinic with severe ear pain, persistent ear discharge, and hearing loss with left facial paralysis for 4 days. Physical examination revealed purulent ear discharge with severe edema of the left ear canal. The temporal computed tomography revealed otomastoiditis. However, temporal magnetic resonance imaging demonstrated a $9 \times 6 \times 5 \mathrm{~mm}$ contrast-enhancing lesion in the internal acoustic canal and thickening in $\mathrm{VII}^{\text {th }}$ and $\mathrm{VIII}$ th cranial nerves. Mastoidectomy was performed for exploration and biopsy. The histopathological results of the mastoid bone and soft tissue samples revealed a relapse of AML. One month after the first chemotherapy regime, ear discharge stopped and facial palsy recovered totally. However, the patient died 9 months after the diagnosis of relapse.

Conclusion: Temporal bone relapse should be suspected in AML patients with symptoms of otomastoiditis and facial palsy. Further investigations including radiological examinations, surgery, and biopsy for avoiding misdiagnosis and delay in treatment are needed.

Keywords: Facial palsy, Granulocytic sarcoma, Leukemia, Mastoiditis

\section{Background}

The incidence of facial paralysis (FP) in children is approximately 2.7 per 100,000 annually, and Bell palsy is the most common cause of paralysis. Infection, trauma, complication of otitis media, and congenital ones are the other reasons of FP [1].

Granulocytic sarcoma (chloroma) is an extramedullary tumor composed of immature myeloid cells as a manifestation of acute myeloid leukemia (AML) with an incidence of $3 \%$ [2]. Although it is a rare condition, the

\footnotetext{
* Correspondence: leventyucel51@hotmail.com

'Department of Otorhinolaryngology, University of Health Sciences, Gülhane Training and Research Hospital, General Dr. Tevfik Sağlam Street, No:1, 06010 Etlik, Ankara, Turkey

Full list of author information is available at the end of the article
}

incidence of this entity in AML M2 (French-AmericanBritish classification) with translocation $(8,21)$ is slightly higher than the other forms of leukemia [3]. Leukemic involvement of the temporal bone with FP is very rare [4]. Bone marrow and peripheral blood involvement usually accompany granulocytic sarcoma; however, it may be the initial finding of AML [5]. Bone marrow involvement may be seen after weeks or months. We present a case with facial paralysis and acute mastoiditis as an initial symptom of acute myeloid leukemia relapse.

\section{Case presentation}

An 8-year-old male with acute myeloid leukemia (AML) $\mathrm{M} 2$ with $\mathrm{t}(8,21)$ (FAB classification) in remission was referred to our clinic with severe ear pain, persistent ear

\section{Springer Open}

(c) The Author(s). 2021 Open Access This article is licensed under a Creative Commons Attribution 4.0 International License, which permits use, sharing, adaptation, distribution and reproduction in any medium or format, as long as you give appropriate credit to the original author(s) and the source, provide a link to the Creative Commons licence, and indicate if changes were made. The images or other third party material in this article are included in the article's Creative Commons licence, unless indicated otherwise in a credit line to the material. If material is not included in the article's Creative Commons licence and your intended use is not permitted by statutory regulation or exceeds the permitted use, you will need to obtain permission directly from the copyright holder. To view a copy of this licence, visit http://creativecommons.org/licenses/by/4.0/. 


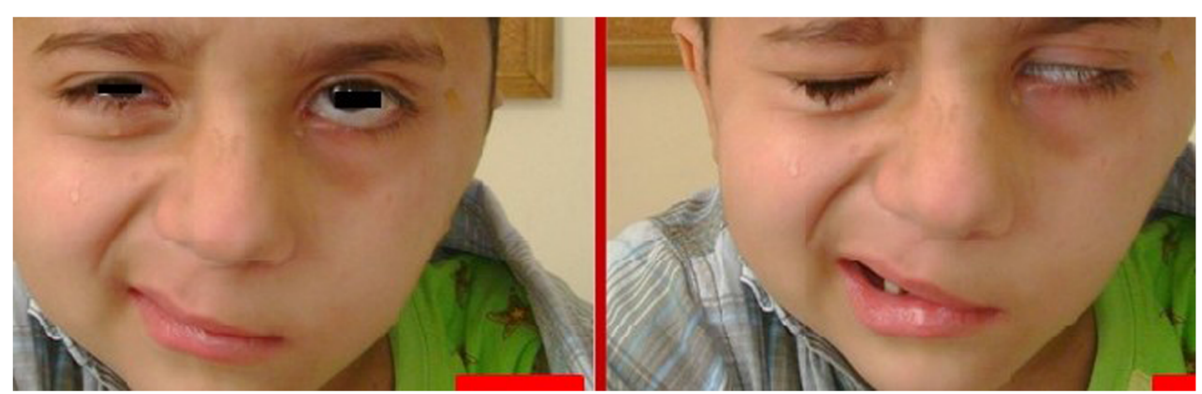

Fig. 1 Left grade 5 facial paralysis according to the House-Brackmann grading system

discharge, and hearing loss with left facial paralysis for 4 days. AML was first diagnosed 2 years ago. He was in remission for 11 months after the first chemotherapy regime; however, the patient underwent hematopoietic stem cell transplantation (HSCT) when he had a relapse of the disease. The complaints of the patient occurred 7 months after the HSCT.

Physical examination revealed purulent ear discharge with severe edema of the left ear canal, due to which the tympanic membrane could not be visualized. He also had grade 5 left facial paralysis according to the HouseBrackmann grading system (Fig. 1).

Temporal computed tomography (CT) and temporal magnetic resonance imaging (MRI) were recommended. Medication for idiopathic facial paralysis and external otitis was started immediately. Systemic steroid (60 mg methylprednisolone, tapered every 3 days), topical ear drops $(0.1 \%$ dexamethasone $3 \times 3$ and $0.3 \%$ ciprofloxacin $3 \times 3$ drops), and eye care were suggested to the patient. Daily ear toilet was performed. Meanwhile, a bone marrow biopsy and a lumbar puncture were performed to check the status of leukemia. The bone marrow biopsy showed no histopathological findings of leukemic relapse or malignancy. Chromosomal analysis of the blood and bone marrow identified that $\mathrm{t}(8,21)$ (q22; q22) was normal. The pediatric neurologist suggested that FP may be caused by toxic neuritis or viral infection.

The temporal CT revealed soft tissue surrounding ossicular structures in mastoid cells and middle ear cavity on the left ear, otomastoiditis without ossicular destruction (Fig. 2). However, temporal MRI demonstrated a 9 $\times 6 \times 5 \mathrm{~mm}$ contrast-enhancing lesion in the internal acoustic canal and thickening in $\mathrm{VII}^{\text {th }}$ and $\mathrm{VIII}^{\text {th }}$ cranial nerves (Fig. 3).

One week after the medical treatment, purulent discharge and facial paralysis improved minimally. Mastoidectomy was performed for exploration and biopsy. Intraoperatively, the mastoid cavity was full of soft tissue. During elevation of the tympanomeatal flap, the thickening of the external ear canal skin was clearly seen and tumor infiltration to the external ear canal was suspected. Biopsy was performed not only from soft tissue but also from the mastoid bone. Furthermore, a new bone marrow biopsy and cerebrospinal fluid (CSF) sample was taken.

There was no evidence of AML or malignancy in examinations of the CSF and bone marrow. The histopathological results of the mastoid bone and soft tissue

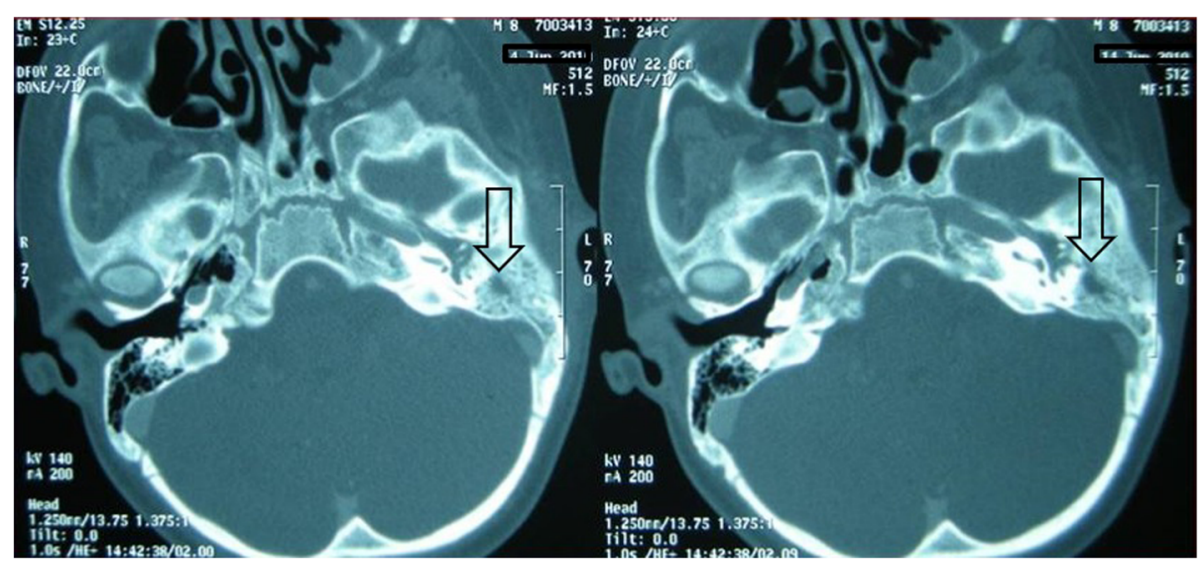

Fig. 2 Axial section of temporal CT: soft tissue surrounding ossicular structures in mastoid cells and middle ear cavity on the left ear, arrows show mastoiditis 


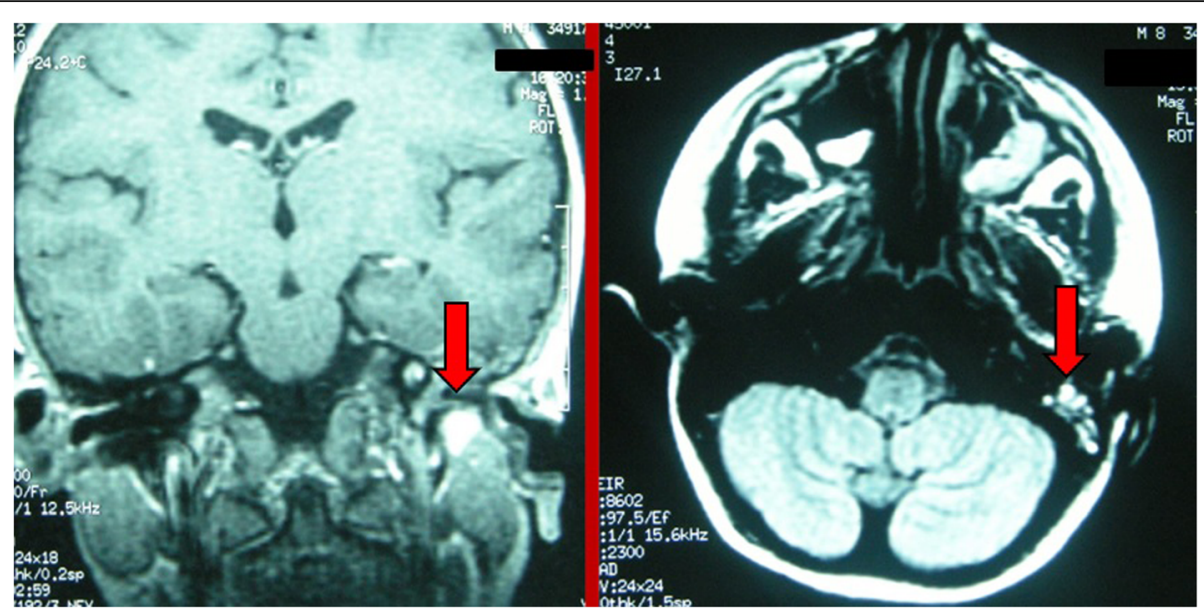

Fig. 3 T1-weighted coronal section and T2-weighted axial section of temporal MRI: arrows show a contrast-enhancing lesion

samples revealed a relapse of AML. The patient was diagnosed as isolated temporal bone extramedullary relapse and transferred to the pediatric hematology department for further treatment. One month after the first chemotherapy regime, ear discharge stopped and facial palsy recovered totally and the patient continued AML treatment in the pediatric hematology department and died 9 months after relapse.

\section{Discussion}

Leukemia is a malignant disease that can affect different locations, and granulocytic sarcoma (chloroma) is an uncommon manifestation of AML [6-9]. There are a few case reports about isolated temporal bone leukemic relapse in the English literature. There is no sex predominance and $40 \%$ of these patients are under 15 years of age. Leukemic involvement of the temporal bone can cause different clinical signs and symptoms such as otalgia, external otitis, hemorrhages of the external ear canal, acute otomastoiditis, and conductive or sensory neural hearing loss $[6,9,10]$. Therefore, facial paralysis is a sign of temporal bone involvement. Leukemic infiltration of perineurium and edema are the causes of paralysis $[7,9]$. There are even a few case reports with facial paralysis as the first symptom of AML $[7,8]$.

Differential diagnosis of facial palsy is difficult especially in an AML patient without systemic relapse and may be easily misdiagnosed as idiopathic Bell palsy or toxic neuritis. Unnecessary treatment and delay in chemotherapy is the most important condition in these patients.

Treatment of chloroma is anti-AML chemotherapy. The prognosis of FP is perfect whereas it is not in AML [5]. Isolated temporal bone relapse of AML is rare, and unfortunately, it is an indicator of poor prognosis. The purpose of the surgery is just obtaining some soft tissue from mastoid bone for histopathological examinations and draining purulent secretion from the mastoid and middle ear. Surgery reduces neoplastic infiltration before chemotherapy. If the tumor involves meningeal spaces through the cochlear duct or by direct extension, intrathecal chemotherapy is mandatory [6].

\section{Conclusions}

Temporal bone relapse should be suspected in AML patients with symptoms of otomastoiditis and facial palsy. Further investigations including radiological examinations, surgery, and biopsy for avoiding misdiagnosis and delay in treatment are needed.

\section{Abbreviations}

AML: Acute myeloid leukemia; FP: Facial paralysis; HSCT: Hematopoietic stem cell transplantation; CT: Computed tomography; MRI: Magnetic resonance imaging; CSF: Cerebrospinal fluid

\section{Acknowledgements}

None

\section{Authors' contributions}

Conception - L.Y. and H.B.; design-L.Y., H.B., and S.B.; supervision-H.B. and S.B.; fundings - not applicable; data collection and/or processing-L.Y. and H.B.; analysis and/or interpretation- L.Y., H.B., and S.B.; literature review-L.Y., H.B., and S.B.; writing manuscript-L.Y. and H.B.; critical review-L.Y., H.B., and S.B. All authors read and approved the manuscript.

\section{Funding}

This study did not receive any specific grant from funding agencies in the public, commercial, or not-for-profit sectors.

Availability of data and materials Not applicable

\section{Declarations}

Ethics approval and consent to participate

Written informed consent for participation in the study was obtained where participants are children (under 16 years old) from the patient's parent. Ethics approval was not required for this case. 


\section{Consent for publication}

Written informed consent for participation in the study was obtained where participants are children (under 16 years old) from the patient's parent for publication of this case report and accompanying images.

\section{Competing interests}

The authors declare that they have no competing interests.

\section{Author details}

'Department of Otorhinolaryngology, University of Health Sciences, Gülhane Training and Research Hospital, General Dr. Tevfik Sağlam Street, No:1, 06010 Etlik, Ankara, Turkey. ${ }^{2}$ Department of Otorhinolaryngology, Faculty of Medicine, University of Ankara, Ankara, Turkey.

Received: 19 February 2021 Accepted: 5 April 2021

Published online: 15 April 2021

\section{References}

1. Psillas G, Antoniades E, leridou F, Constantinidis J (2019) Facial nerve palsy in children: a retrospective study of 124 cases. J Paediatr Child Health. 55(3): 299-304. https://doi.org/10.1111/jpc.14190

2. Howell J, Segel J, Jajosky R, Savage NM, Fields B, Kota V, Mowry S (2015) Acute facial paralysis and otomastoiditis as presenting symptoms of myeloid sarcoma. Otol Neurotol. 36(4):e104-e1e6. https://doi.org/10.1097/ MAO.0000000000000490

3. Tallman MS, Hakimian D, Shaw JM, Lissner GS, Russell EJ, Variakojis D (1993) Granulocytic sarcoma is associated with the 8; 21 translocation in acute myeloid leukemia. J Clin Oncol. 11(4):690-697. https://doi.org/10.1200/JCO.1 993.11.4.690

4. Kubota K, Ozeki M, Hori T, Kanda K, Funato M, Asano T, Fukao T, Kondo N (2014) Facial palsy as an unusual presenting symptom associated with acute myeloid leukemia. Pediatr Int 56(4):e37-e40. https:/doi.org/10.1111/ped.12384

5. Young CW, Ho CS, Chiu NC, Liu HC, Liang DC (2016) Acute myeloid leukemia with initial presentation of facial palsy and exophthalmos. Acta Neurol Taiwan. 25(1):18-20

6. Almadori G, Del Ninno M, Cadoni G, Di Mario A, Ottaviani F (1996) Facial nerve paralysis in acute otomastoiditis as presenting symptom of FAB M2, T8; 21 leukemic relapse. Case Report and review of the literature. Int J Pediatr Otorhinolaryngol. 36(1):45-52. https://doi.org/10.1016/01655876(95)01323-7

7. Sood BR, Sharma B, Kumar S, Gupta D, Sharma A (2003) Facial palsy as first presentation of acute myeloid leukemia. Am J Hematol. 74(3):200-201. https://doi.org/10.1002/ajh.10406

8. Cureoglu S, Tulunay O, Ferlito A, Schachern PA, Paparella MM, Rinaldo A (2004) Otologic manifestations of metastatic tumors to the temporal bone. Acta Otolaryngol. 124(10):1117-1123. https://doi.org/10.1080/0001648041 0018052

9. Chang KH, Kim DK, Jun BC, Park YS (2009) Temporal bone myeloid sarcoma. Clin Exp Otorhinolaryngol. 2(4):198-202. https://doi.org/10.3342/ceo.2 009.2.4.198

10. Todd NW Jr, Bowman CA (1984) Acute myelogenous leukemia presenting as atypical mastoiditis with facial paralysis. Int J Pediatr Otorhinolaryngol. 7(2):173-177. https://doi.org/10.1016/S0165-5876(84)80041-5

\section{Publisher's Note}

Springer Nature remains neutral with regard to jurisdictional claims in published maps and institutional affiliations.

\section{Submit your manuscript to a SpringerOpen ${ }^{\circ}$ journal and benefit from:}

- Convenient online submission

- Rigorous peer review

Open access: articles freely available online

- High visibility within the field

- Retaining the copyright to your article

Submit your next manuscript at $\boldsymbol{\nabla}$ springeropen.com 